
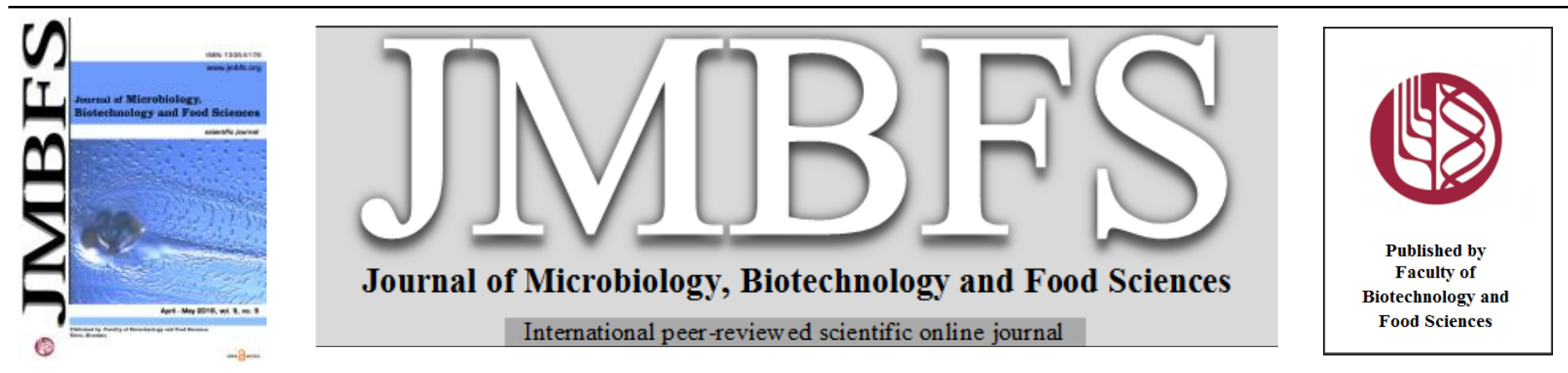

\title{
NUTRITIONAL PROFILES OF PROCESSED Spondias mombin FOLIAGE AND PHYSIOLOGICAL RESPONSE OF RUMEN MICROORGANISMS TO THE EXTRACTS
}

\author{
Kingsley Omogiade IDAHOR*' and Michael Kolawole ADEWUMI \\ Address(es): \\ ${ }^{1}$ Department of Animal Science, Nasarawa State University, Keffi, Shabu-Lafia Campus, P.M.B. 135, Lafia, 950101, Nigeria. \\ ${ }^{2}$ Department of Animal Science, University of Ibadan, Ibadan, Nigeria.
}

*Corresponding author: omokingida@yahoo.com

doi: $10.15414 / j m b f s .2016 .5 .5 .434-439$

\section{ARTICLE INFO}

Received 28. 9. 2014

Revised 26. 11. 2015

Accepted 25. 12. 2015

Published 1. 4. 2016

Regular article

open 2 ACCESS

\begin{abstract}
Spondias mombin foliage was processed into fresh (as control), air-dried and sun-dried samples and were analyzed for proximate, fibre, minerals, vitamins and antinutrients. Also, Identified rumen microorganisms were exposed to non-reconstituted ethanol extract of the foliage. The results showed that crude protein, crude fibre and gross energy were greatly improved by drying from $4.9 \%$ to $15.1 \%, 2.1 \%$ to $18.4 \%$ and $0.9 \mathrm{kcal} / \mathrm{g}$ to $2.9 \mathrm{kcal} / \mathrm{g}$ in that order. Fibre constituents improved from $11.5 \%$ to $67.9 \%, 7.2 \%$ to $53.6 \%$ and $2.9 \%$ to $9.3 \%$ for neutral detergent fibre, acid detergent fibre and acid detergent lignin. Similarly, all the mineral components were improved from $0.083 \%$ to $0.21 \%, 0.193 \%$ to $0.533 \%$ and $0.073 \%$ to $0.23 \%$ for Calcium, Phosphorus and Sodium respectively by drying. Drying decreased the Ascorbic acid, Riboflavin and Niacin contents from $27.8 \mathrm{mg} / 100 \mathrm{~g}$ to $9.1 \mathrm{mg} / 100 \mathrm{~g}, 0.083 \mathrm{mg} / 100 \mathrm{~g}$ to $0.033 \mathrm{mg} / 100 \mathrm{~g}$ and $0.323 \mathrm{mg} / 100 \mathrm{~g}$ to $0.143 \mathrm{mg} / 100 \mathrm{~g}$ in that arrangement. Above all, it was observed that drying tremendously improved the nutritional value of S. mombin foliage by reducing tannin from $2.2 \%$ to $1.64 \%$, oxalic acid ( $2.1 \%$ to $1.38 \%$ ), phytic acid (1.15 to $0.45 \%)$, saponin ( $1.18 \%$ to $0.72 \%$ ) and trypsin inhibitor from $39.74 \%$ to $16.57 \%$. However, drying did not influence the toxic potential of the foliage as indicated by susceptibility of all the rumen microorganisms except the mould species. The nutritional quality potentials observed in the present study suggested that $S$. mombin foliage may be efficiently utilized by ruminants for optimal performance.
\end{abstract}

\section{INTRODUCTION}

Spondias mombin commonly called yellow mombin belongs to the Anacardiaceae family. It is well distributed across Mexico, South America and widely cultivated in Paleotropics and native range in West Indies. It is a multipurpose shrub of enormous economic values as food (i.e. the fruits), fence (i.e. boundary demarcation), environmental ornament and antitumour agent (Idu et al., 2002; Wiersema and Leon, 1999). Yet, there is insufficient reports on its possible utilization as fodder in ruminant nutrition particularly in Nigeria, where it grows everywhere in the rainforest belt. Although it is a deciduous shrub, it has a very high aftermath capability indicating high biomass fodder availability at all times. Since grasses and agricultural waste have been speculated to be inadequate for optimum ruminant productivity, shrubs and trees with potential feeding values should be evaluated for diet supplementation, especially during off season when grasses and agro byproducts may not be readily available.

Several researches have shown that feed resource evaluation is an important tool that provides useful information necessary for diet formulation in order to optimize performance. In series of experimental studies, it was established that rumen microorganisms are responsible for feedstuff degradability, digestibility and utilization by the host ruminant. But the earliest research frontiers however dwelled so much on feedstuff quality testing using chemical constituen technique (Midkiff, 1984), gas production technique (Menke et al., 1979) and cell-free fungal cellulose technique (De-Boever et al., 1986). Also, nylon bags technique and feed resource digestion technique with unidentified/mixed rumen microorganisms were used to determine the nutritional quality of feedstuff meant for ruminants (Mehrez and Orskov, 1977; Tilley and Terry, 1963). Unfortunately, some of these techniques were somewhat not adopted in animal agriculture probably due to some forms of complexities. Above all, feed resource quality evaluation using a mixed culture of rumen microorganisms may not have actually indicated which rumen microorganism was actively involved in the gas production or the fermentation processes (Makkar, 2004; Sullivan and Martin, 1999). Consequently in vitro exposure of pure culture rumen microorganisms to feedstuff sample could be a novel and better technique of feed quality evaluation.
Hence, the present study examined the nutritional profile and susceptibility of rumen microorganisms to ethanol extract of $S$. mombin foliage.

\section{MATERIALS AND METHODS}

\section{Samples preparation}

Fresh foliage of $S$. mombin was collected from the University of Ibadan Campus and authenticated at the Herbarium, Department of Botany and Microbiology at the same University. Two hundred and fifty grams $(250 \mathrm{~g})$ of the foliage without leaf stalk was weighed and processed as fresh, air-dried and sun-dried samples. The fresh sample (which served as the control) was crushed in a mortar (Pyrex $\left.{ }^{\circledR}\right)$ and stored in the freezer. The sample for air-drying (i.e. indoor drying) was spread on the bench in a well-ventilated laboratory at the Institute of Agricultural Research and Training, Ibadan, at a mean room temperature of $28.5^{\circ} \mathrm{C}$ for $48 \mathrm{hrs}$ Sample for sun-drying (i.e. outdoor drying) was spread on a special drying platform at a mean temperature of $33.2^{\circ} \mathrm{C}$ for 2 days between 08.00 and $16: 00 \mathrm{hr}$ GMT each day. The air-dried and sun-dried samples were crispy dried yet retained the green colour. Thereafter, they were ground using hammer mill (Arthur Thomas Co. USA) to a mesh size of $2 \mathrm{~mm}$ and stored in a cool dry shelf in the laboratory. In a cold extraction, $1 \mathrm{~g}$ of each sample was thoroughly mixed with $40 \mathrm{ml}$ of ethanol $(80 \%)$. The mixture was left overnight and was filtered using Whitman No. 1 filter paper ${ }^{\circledR}$. Although concentration of the bioactive ingredients of the filtrate was not determined, it was heated for 2 mins to get rid of the ethanol while the pure extract which was not also quantified was stored in McCartney bottles kept in the refrigerator.

\section{Nutrients and antinutrients determination}

While the fresh Spondias mombin foliage samples were analyzed as wet basis (control treatment), the dried samples were analyzed on dry matter basis for proximate compositions according to AOAC (2000). The fibre constituents were determined following the description of van Soest et al. (1991). The mineral and vitamin contents were estimated adopting the methods of Wiseman and Cole 
(1990) while the gross energy was measured with an adiabatic bomb calorimeter (IKA C7000, Staufen - Germany) standardised with benzoic acid as prescribed by Witt (1987)

Haemagglutinin was estimated as described by Liener (1955), mimosine (Megarrity, 1978), cyanide (Bradbury, 1999), trypsin inhibitor (Smith et al. 1980), Oxalic acid (Bateman and Beer, 1965) while the alkaloid content was evaluated according to Henry (1973). The phytic acid was determined as demonstrated by Vaintraub and Lapteva (1988) and the total saponin and tannin contents were analyzed using the methods of Makkar et al. (1993).

\section{Isolation and identification of rumen microorganisms}

Samples of rumen liquor were collected in sterile bottles from cattle and goats just slaughtered at Bodija abattoir, Ibadan. Meanwhile, what the animals were fed prior to liquor collection was not taken into cognizance. The samples were pooled and $1 \mathrm{~g}$ was thoroughly mixed with $9 \mathrm{ml}$ of distilled water in a serial dilution procedure given by Black (1986). In an aseptical condition, $1 \mathrm{ml}$ of the serial dilution was mixed with $5 \mathrm{ml}$ of sterile Eosin Methylene Blue - EMB (idg Lab $\mathrm{M}^{\mathrm{TM}}$, UK) and Plate Count Agar - PCA (idg Lab $\mathrm{M}^{\mathrm{TM}}$, UK) for rumen bacteria isolation. The mixture was incubated using Temperaturregler $(\mathrm{GmbH}$ Germany) at $37^{\circ} \mathrm{C}$ for $48 \mathrm{hrs}$ under anaerobic condition recommended by Levett (1990). Subculture of the growth observed was done by flaming and streaking followed by incubation at $37^{\circ} \mathrm{C}$ overnight to obtain pure isolates.

Using flamed inoculating wire loop, samples were collected from the pure isolates in an Oxygen free atmosphere and further subcultured in a liquid substrate "Peptone Water Broth" (idg Lab M ${ }^{\mathrm{TM}}$, UK) and stored in an incubator a $35^{\circ} \mathrm{C}$. Similarly, $1 \mathrm{ml}$ of the serial dilution was mixed with $5 \mathrm{ml}$ of sterile Potato Dextrose Agar - PDA (DM215, Micro Master Laboratories $\left.{ }^{\circledR}\right)$ and an antibiotic (Vanclox, Evans ${ }^{\circledR}$ ) was added to prevent bacterial growth and then incubated for 4 days at $34^{\circ} \mathrm{C}$ according to Kudo et al. (1990). The rumen fungal isolates were purified and transferred into liquid broth (Malt Extract: Difco Laboratories, USA) stored in an incubator at $35^{\circ} \mathrm{C}$. The rumen bacteria pure isolates were subjected to morphological and biochemical tests as reported by Yokoyama and Johnson (1993). Meanwhile, the procedure was modified to include antibiosis (i.e. Ionophore and Avopacin) for detailed characterization of the rumen microbia strains. Originally, Avopacin and Ionophore (monesin, lasalocid) were used to depress certain rumen microbial strains in order to improve feed utilization efficiency (Aderinboye and Onwuka, 2010; Yokoyama and Johnson, 1993) The rumen fungi isolates were identified according to Kudo et al. (1990). The identification features were modified to include some structural characteristics like reproductive stage, sporangiophore, mycelium and rhizoid for proper characterization of the rumen fungal strains. Although concentration of the $S$ mombin foliage extract was not estimated, susceptibility of the rumen microorganisms was examined by subjecting each of the identified rumen bacteria and fungi to the $S$. mombin foliage non-reconstituted pure extract. Each of the 12-punched-well agars was filled with the non-reconstituted foliage extract, streaked with each of the identified rumen microorganisms at a time and incubated overnight in the case of rumen bacteria and 4days for rumen fungi (Levett, 1990)

\section{Experimental design, data collection and analysis}

Randomized Completely Block Design where the feedstuff processing technique was blocked was adopted and all the parameters were determined in triplicates. Data were collected on proximate compositions, fibre components, mineral and vitamin contents as well as antinutritional constituents of the fresh, air-dried and sun-dried $S$. mombin foliage. Also, information on the suspected rumen microorganisms following morphological examination and biochemical tests were recorded. The growth pattern around each of the wells was observed and recorded as minimum inhibition concentration after overnight and 4 days incubation periods for the identified rumen bacteria and fungi respectively (Black, 1986). The sets of data obtained were subjected to analysis of variance procedure of SAS (1999) and the means were separated as given by Duncan's multiple range test of the same software package.

\section{RESULTS AND DISCUSSION}

\section{Nutritional compositions}

The nutrient compositions of processed $S$. mombin foliage are given in Table 1. All the parameters measured were significantly improved $(\mathrm{P}<0.05)$ by air-drying and sun-drying compared to the control treatment. Meanwhile the sun-dried values were superior in all the cases except in gross energy and cellulose, where there were no statistical differences $(\mathrm{P}<0.05)$ in the air-dried and sun-dried values. The crude protein value ranged from $4.9 \%$ in control to $10.3 \%$ (air-dried) and $15.1 \%$ in sundried. Ether extract, crude fibre and ash values were $1.3 \%, 2.1 \%$ and $2.8 \%$ in control compared to $13.3 \%, 18.4 \%$ and $13.8 \%$ in sun-dried. The energy value varied from $2.5 \mathrm{kcal} / \mathrm{g}$ in air-dried to $2.9 \mathrm{kcal} / \mathrm{g}$ in sundried compared to as low as $0.9 \mathrm{kcal} / \mathrm{g}$ in control. The neutral detergent fibre, acid detergent fibre and acid detergent lignin values which were as high as $67.9 \%, 53.6 \%$ and $9.3 \%$ respectively in sun-dried, was slightly followed by air-dried $(43.8 \%, 21.9 \%$ and $6.8 \%)$ with the least values $(11.5 \%, 7.2 \%$ and $2.9 \%)$ in control.

The observed nutritional values contradicted the report of Ikhimioya and Oriakhi (2004) where fresh $S$. mombin leaves had $10.06 \%$ crude protein and dry leaves $6.41 \%$. Although the crude protein contents (4.9 to $15.1 \%$ ) observed in the present study were less than $18.83 \%$ reported by Mecha and Adegbola (2006), they were within the reported values $3.6-22.5 \%$ (ESGPIP, 2008), $5.08-$ $10.06 \%$ (Ikhimioya and Oriakhi, 2004) and recommended range value of 1.61 $7.76 \mathrm{~g}$ per kilogram metabolic weight $\left(\mathrm{W}^{0.75}\right)(\mathrm{NRC}, 1981)$ for ruminant nutrition. The ether extract, crude fibre and ash contents observed were within $0.7-9.3 \%$ $7.8-40.7 \%$ and $1.0-12.5 \%$ respectively recorded in some forages (Mecha and Adegbola, 2006). Meanwhile, the energy value was less than $0.7-6.88 \mathrm{Mca}$ recommended by NRC (1981) for optimal ruminant productivity. However, all the values were in agreement with the nutritional requirements recommended by Givens et al. (2000). The range values of neutral detergent fibre (11.5-67.9\%), acid detergent fibre $(7.2-53.6 \%)$ and cellulose $(4.3-44.3 \%)$ were within 18.31 - $68.87 \%$ recorded in some other ruminant feed resources (Idahor et al., 2012; Rosiji and Iposu, 2002).

Also, drying was observed to significantly improved $(\mathrm{P}<0.05)$ all the minerals determined. Calcium, Iron, Magnesium, Potassium and Phosphorus values were highest $(0.21 \%, 0.003 \%, 0.353 \%, 0.463 \%$ and $0.533 \%)$ in sun-dried followed by air-dried $(0.17 \%, 0.002 \%, 0.193 \%, 0.343 \%$ and $0.153 \%)$ and control $(0.083 \%$, $0.001 \%, 0.093 \%, 0.153 \%$ and $0.193 \%$ ). Furthermore, Sodium, Zinc, Copper and Manganese values were highest $(0.233 \%, 0.0034 \%, 0.0009 \%$ and $0.004 \%$ respectively) in sun-dried sample and slightly followed by air-dried sample ( $0.153 \%, 0.0029 \%, 0.0005 \%$ and $0.003 \%)$ with the least $(0.73 \%, 0.002 \%$, $0.0002 \%$ and $0.001 \%$ ) in fresh sample (control). The Magnesium, Phosphorus, Potassium and Sodium values were within the ranges $0.04-0.25 \%, 0.16-0.4 \%$ $0.5-0.8 \%$ and $0.06-0.18 \%$ respectively recommended for ruminant animals (NRC 1981).

However, the Calcium level was less than $0.21-0.58 \%$ recommended for optimal ruminant productivity (Church, 1993; NRC, 1981).

In all the vitamins evaluated, it was observed that dry processing significantly depressed $(\mathrm{P}<0.05)$ the values compared to the control. The Ascorbic acid Riboflavin and Niacin values varied from 9.1 to $15.4 \mathrm{mg} / 100 \mathrm{~g}, 0.033$ to $0.053 \mathrm{mg} / 100 \mathrm{~g}$ and 0.143 to $0.213 \mathrm{mg} / 100 \mathrm{~g}$ ) in sun- dried and air-dried samples but were quite high $(27.8 \mathrm{mg} / 100 \mathrm{~g}, 0.083 \mathrm{mg} / 100 \mathrm{~g}$ and $0.323 \mathrm{mg} / 100 \mathrm{~g})$ in control. The levels of Riboflavin and Niacin observed were less than $4.5-32 \mathrm{mg} / 100 \mathrm{~kg}$ BW and $26-182 \mathrm{mg} / 100 \mathrm{~kg}$ BW respectively recommended for ruminant animals. This observation concurred with the earlier report by Wiseman and Cole (1990) that vitamins were insufficient in processed feed hence their inclusion in ruminant nutrition is essential. The observed depression in the vitamin values could be largely due to their nature as biologically active biochemical compounds that are generally sensitive to their physical and chemical environments. According to Coelho, (1999), several vitamins contain unsaturated carbon atoms or have double bonds that make them highly susceptible to oxidation. Although, feed processing tend to improve the distribution and digestibility of nutrients, it could be harmful to heat labile nutrients such as vitamins that can easily oxidized (Gadient, 1986; Schneider, 1986)

It was observed that all the fresh sample values were seemingly lower, suggesting feed drying (particularly in hay form) superiority over fresh form (fodder). The observed distinct disparities in all the values recorded in the nutritional parameters, could be largely due to the moisture contents and possibly due to denaturation of heat-labile nutrients thereby enhancing the concentration of others. While, the disparities with other reported values could be due to the agro climatic differences, stage of growth, plant species and the laboratory protocols adopted. 
Table 1 Effect of processing on nutritional profiles of S. mombin foliage

\begin{tabular}{|c|c|c|c|c|}
\hline \multirow{2}{*}{ Parameters $(\dagger \dagger)$} & \multicolumn{4}{|c|}{ Processing techniques } \\
\hline & Fresh & Air-dried & Sun-dried & SEM \\
\hline \multicolumn{5}{|l|}{ Proximate } \\
\hline Organic matter (\%) & $97.3^{\mathrm{b}}$ & $91.0^{\mathrm{ab}}$ & $86.2^{\mathrm{a}}$ & 0.01 \\
\hline Crude protein (\%) & $4.9^{\mathrm{a}}$ & $10.3^{\mathrm{b}}$ & $15.1^{\mathrm{c}}$ & 0.01 \\
\hline Ether extract (\%) & $1.3^{\mathrm{a}}$ & $7.5^{\mathrm{b}}$ & $13.3^{\mathrm{c}}$ & 0.01 \\
\hline Crude fibre (\%) & $2.1^{\mathrm{a}}$ & $8.8^{\mathrm{b}}$ & $18.4^{\mathrm{c}}$ & 0.01 \\
\hline $\operatorname{Ash}(\%)$ & $2.8^{\mathrm{a}}$ & $9.1^{\mathrm{b}}$ & $13.8^{\mathrm{c}}$ & 0.01 \\
\hline Gross energy (kcal/g) & $0.9^{\mathrm{a}}$ & $2.5^{\mathrm{b}}$ & $2.9^{\mathrm{b}}$ & 0.07 \\
\hline \multicolumn{5}{|l|}{ Fibre constituents (\%) } \\
\hline Neutral detergent fibre & $11.5^{\mathrm{a}}$ & $43.8^{\mathrm{b}}$ & $67.9^{\mathrm{c}}$ & 0.01 \\
\hline Acid detergent fibre & $7.2^{\mathrm{a}}$ & $21.9^{\mathrm{b}}$ & $53.6^{\mathrm{c}}$ & 0.01 \\
\hline Acid detergent lignin & $2.9^{\mathrm{a}}$ & $6.8^{\mathrm{b}}$ & $9.3^{c}$ & 0.01 \\
\hline Cellulose & $4.3^{\mathrm{a}}$ & $15.1^{\mathrm{b}}$ & $44.3^{\mathrm{c}}$ & 0.02 \\
\hline Hemicellulose & $4.3^{\mathrm{a}}$ & $22.0^{\mathrm{b}}$ & $14.3^{\mathrm{c}}$ & 0.02 \\
\hline \multicolumn{5}{|l|}{ Minerals (\%) } \\
\hline Calcium & $0.083^{\mathrm{a}}$ & $0.17^{\mathrm{b}}$ & $0.21^{\mathrm{b}}$ & 0.01 \\
\hline Iron & $0.001^{\mathrm{a}}$ & $0.002^{\mathrm{ab}}$ & $0.003^{\mathrm{b}}$ & 0.02 \\
\hline Magnesium & $0.093^{\mathrm{a}}$ & $0.193^{\mathrm{b}}$ & $0.353^{\mathrm{c}}$ & 0.01 \\
\hline Potassium & $0.153^{\mathrm{a}}$ & $0.343^{\mathrm{b}}$ & $0.463^{\mathrm{c}}$ & 0.01 \\
\hline Phosphorus & $0.193^{\mathrm{a}}$ & $0.343^{\mathrm{b}}$ & $0.533^{\mathrm{c}}$ & 0.01 \\
\hline Sodium & $0.073^{\mathrm{a}}$ & $0.153^{\mathrm{b}}$ & $0.233^{\mathrm{b}}$ & 0.01 \\
\hline Zinc & $0.002^{\mathrm{a}}$ & $0.0029^{\mathrm{b}}$ & $0.0034^{\mathrm{b}}$ & 0.02 \\
\hline Copper & $0.0002^{\mathrm{a}}$ & $0.0005^{\mathrm{b}}$ & $0.0009^{c}$ & 0.02 \\
\hline Manganese & $0.001^{\mathrm{a}}$ & $0.003^{\mathrm{b}}$ & $0.004^{\mathrm{b}}$ & 0.02 \\
\hline \multicolumn{5}{|l|}{ Vitamins (mg/100g) } \\
\hline Ascorbic acid & $27.8^{\mathrm{c}}$ & $15.4^{\mathrm{b}}$ & $9.1^{\mathrm{a}}$ & 0.01 \\
\hline Riboflavin & $0.083^{\mathrm{c}}$ & $0.053^{\mathrm{b}}$ & $0.033^{\mathrm{a}}$ & 0.01 \\
\hline Niacin & $0.323^{\mathrm{c}}$ & $0.213^{\mathrm{b}}$ & $0.143^{\mathrm{a}}$ & 0.01 \\
\hline
\end{tabular}

\section{Toxic factor components}

The antinutrients determined in S. mombin foliage are shown in Table 2. It was discovered that drying drastically reduced $(\mathrm{P}<0.05)$ all the antinutrients concentrations. The determined phytic acid, oxalic acid, tannin and saponin levels that were as high as $1.15 \%, 2.1 \%, 2.21 \%$ and $1.18 \%$ respectively in the fresh sample, were reduced to as low as $0.45-0.54 \%, 1.38-1.53 \%, 1.64-$ $2.04 \%$ and $0.72-0.93 \%$ by drying. Also, the alkaloid, cyanide, mimosine, haemaglutinin and trypsin inhibitor concentrations declined from $2.37 \%$ $84.74 \mathrm{mg} / \mathrm{kg}, 3.92 \mathrm{mg} / 100 \mathrm{~g}, 9.66 \mathrm{HIU} / \mathrm{mg}$ protein and $39.74 \%$ accordingly in the fresh sample to as low as $1.1-1.55 \%, 36.04-66.92 \mathrm{mg} / \mathrm{kg}, 1.55-2.13 \mathrm{mg} / 100 \mathrm{~g}$, $4.14-7.69 \mathrm{HIU} / \mathrm{mg}$ protein and $16.57-21.32 \%$ after drying.
Table 2 Effect of processing on antinutrients components of S. mombin foliage

\begin{tabular}{|c|c|c|c|c|}
\hline \multirow{2}{*}{ Antinutrients $(\dagger \dagger)$} & \multicolumn{4}{|c|}{ Processing techniques } \\
\hline & Fresh & Air-dried & Sun-dried & SEM \\
\hline Phytic acid (\%) & $1.15^{\mathrm{b}}$ & $0.45^{\mathrm{a}}$ & $0.54^{\mathrm{a}}$ & 0.01 \\
\hline Oxalic acid (\%) & $2.1^{\mathrm{b}}$ & $1.53^{\mathrm{a}}$ & $1.38^{\mathrm{a}}$ & 0.02 \\
\hline Tannin $(\%)$ & 2.21 & 2.04 & 1.64 & 0.01 \\
\hline Saponin (\%) & 1.18 & 0.93 & 0.72 & 0.01 \\
\hline Alkaloid (\%) & $2.37^{\mathrm{b}}$ & $1.55^{\mathrm{a}}$ & $1.1^{\mathrm{a}}$ & 0.01 \\
\hline Cyanide $(\mathrm{mg} / \mathrm{kg})$ & $84.74^{\mathrm{c}}$ & $66.92^{\mathrm{b}}$ & $36.04^{\mathrm{a}}$ & 0.01 \\
\hline Mimosine $(\mathrm{mg} / 100 \mathrm{~g})$ & $3.92^{\mathrm{b}}$ & $2.13^{\mathrm{a}}$ & $1.55^{\mathrm{a}}$ & 0.02 \\
\hline $\begin{array}{l}\text { Haemaglutinin(HIU/mg } \\
\text { protein) }\end{array}$ & $9.66^{\mathrm{c}}$ & $7.69^{\mathrm{b}}$ & $4.14^{\mathrm{a}}$ & 0.02 \\
\hline Trypsin inhibitor (\%) & $39.74^{\mathrm{c}}$ & $21.32^{\mathrm{b}}$ & $16.57^{\mathrm{a}}$ & 0.02 \\
\hline
\end{tabular}

The phytic acid and saponin concentrations were less than $3.1 \%$ and $5.0 \%$ respectively reported in Moringa oleifera leaves which Makkar and Becker (1996) described as innocuous. However, the tannin concentration was higher than $0.62 \%$ detected in Sesbania (Reed 1986) and 2.05\% found in Gliricidia (Ahn et al., 1989) but was lower than $3.0-14.0 \%$ reported in Leucaena (D'Mello and Fraser 1981). Also, the mimosine and saponin concentrations were observed to be less than $12.0 \%$ and $11.0 \%$ respectively discovered in Leucaena (Tangendjaja et al., 1990). Since Barry and McNabb (1999) reported that tannin concentration greater than $4.0 \%$ could depress feed intake and there are several reports that ruminants can tolerate and utilize some levels of antinutrients (Hoskin et al., 1997), S. mombin foliage could be a suitable feed resource in ruminant production.

More significantly, the oxalic acid, trypsin inhibitor, alkaloid, haemaglutinin and cyanide values were less than the threshold levels reported in livestock (Olomu, 2011). The relatively safe levels estimated in all the antinutrients determined, could be probably due to the part collected and maturity of the foliage. The observed supremacy of feedstuff drying technique could explain the need for proper feed processing prior to utilization in ruminant nutrition.

\section{Susceptibility of the identified rumen microorganisms}

The morphological examinations and biochemical tests of the rumen microorganisms are shown in Tables 3 and 4. The identified rumen bacteria were Bacteroides ruminicola, B. succinogenes, Butyrivibrio fibrisolvens and Lactobacillus ruminus. Others were Ruminococcus albus, R. flavefaciens, Selenomonas ruminantium and Streptococcus bovis. The rumen fungi strains were Neocallimastix frontalis, Orpinomyces joyonii, Saccharomyces cerevisiae, Mucor species, Caecomyces communis and Rhizopus species. The kinds of rumen microorganisms that were recorded in the rumen liquor could be possibly due to the nature of feed the hosts (cattle and goats) were fed and probably due to their age.

Table 3 Morphological and biochemical tests of the rumen bacterial isolates

\begin{tabular}{|c|c|c|c|c|c|c|c|c|c|c|c|}
\hline \multirow{3}{*}{$\begin{array}{l}\text { Isolate } \\
\text { code No. }\end{array}$} & \multirow{2}{*}{\multicolumn{2}{|c|}{$\begin{array}{l}\text { Morph. Exams } \\
\text { Gram stain } \\
\end{array}$}} & \multicolumn{8}{|c|}{ Biochemical tests } & \multirow{3}{*}{$\begin{array}{l}\text { Suspected } \\
\text { microorganism }\end{array}$} \\
\hline & & & \multicolumn{3}{|c|}{ Proteolysis } & \multicolumn{2}{|c|}{ Amylolysis } & & \multicolumn{2}{|c|}{ Antibiosis } & \\
\hline & $\mathrm{Gr}$ & Shape & Gel & Cas & L.mil & Star & Cellu & Sucr & Iono & Avop & \\
\hline $\mathrm{PCACC}_{1}^{\mathrm{a}}$ & - & Cocci & - & - & + & - & - & - & $\mathrm{R}$ & $\mathrm{R}$ & Selenomonas ruminantium \\
\hline $\mathrm{PCACC}_{1}^{\mathrm{b}}$ & + & Cocci & - & - & - & + & + & + & $\mathrm{S}$ & $\mathrm{S}$ & Ruminococcus albus \\
\hline $\mathrm{PCAC}_{4}$ & - & Rods & + & + & + & + & - & - & $\mathrm{S}$ & $\mathrm{S}$ & Butyrivibrio fibrisolvens \\
\hline $\mathrm{PCA} \mathrm{C}_{5}$ & + & Cocci & - & - & - & - & + & - & $\mathrm{S}$ & $\mathrm{S}$ & Ruminococcus flavefaciens \\
\hline $\mathrm{PCAC}_{7}$ & + & Cocci & - & - & + & - & - & - & $\mathrm{R}$ & $\mathrm{R}$ & Selenomonas ruminantium \\
\hline $\mathrm{PCA} \mathrm{C}_{8}$ & + & Cocci & - & - & + & - & - & - & $\mathrm{R}$ & $\mathrm{R}$ & Selenomonas ruminantium \\
\hline $\mathrm{PCAC}_{9}$ & + & Cocci & - & - & + & - & - & - & $\mathrm{R}$ & $\mathrm{R}$ & Selenomonas ruminantium \\
\hline $\mathrm{PCAC}_{10}{ }^{\mathrm{a}}$ & + & Cocci & - & - & - & - & + & - & $\mathrm{S}$ & $\mathrm{S}$ & Ruminococcus flavefaciens \\
\hline $\mathrm{PCA} \mathrm{C}_{10}{ }^{\mathrm{b}}$ & + & Cocci & - & - & - & + & + & + & $\mathrm{S}$ & $\mathrm{S}$ & Ruminococcus albus \\
\hline $\mathrm{PCA} \mathrm{G}_{1}$ & - & Rods & + & + & + & + & + & + & $\mathrm{R}$ & $\mathrm{R}$ & Bacteriodes ruminicola \\
\hline $\mathrm{PCA} \mathrm{G}_{2}$ & - & Rods & + & + & + & + & + & + & $\mathrm{R}$ & $\mathrm{R}$ & Bacteriodes ruminicola \\
\hline $\mathrm{PCA} \mathrm{G}_{3}$ & + & Rods & + & + & + & + & - & - & $\mathrm{S}$ & $\mathrm{S}$ & Butyrivibrio fibrisolvens \\
\hline $\mathrm{PCA} \mathrm{G}_{4}$ & + & Rods & + & + & + & + & - & - & $S$ & S & Butyrivibrio fibrisolvens \\
\hline $\mathrm{PCA} \mathrm{G}_{6}$ & - & Rods & - & - & - & + & + & + & $\mathrm{R}$ & $\mathrm{S}$ & Bacteroides succinogenes \\
\hline $\mathrm{PCA} \mathrm{G}_{8}$ & - & Rods & + & + & + & + & + & + & $\mathrm{R}$ & $\mathrm{R}$ & Bacteroides ruminicola \\
\hline $\mathrm{PCA} \mathrm{G}_{9}$ & - & Rods & + & + & + & + & + & + & $\mathrm{R}$ & $\mathrm{R}$ & Bacteroides rumincola \\
\hline EMB $C_{1}$ & - & Rods & + & + & + & + & + & + & $\mathrm{R}$ & $\mathrm{R}$ & Bacteroides rumincola \\
\hline $\mathrm{EMB} \mathrm{C}_{2}{ }^{\mathrm{a}}$ & - & Rods & + & + & + & + & + & + & $\mathrm{R}$ & $\mathrm{R}$ & Bacteroides rumincola \\
\hline EMB C ${ }_{2}^{\text {b }}$ & + & Cocci & + & + & + & + & + & + & $\mathrm{S}$ & $\mathrm{R}$ & Streptococcus bovis \\
\hline $\mathrm{EMB} \mathrm{C}_{6}$ & + & Cocci & - & - & - & - & + & - & $\mathrm{S}$ & $\mathrm{S}$ & Ruminococcus flavefaciens \\
\hline EMB C $_{10}$ & - & Rods & - & - & - & + & + & + & $\mathrm{R}$ & $\mathrm{S}$ & Bacteroides succinogenes \\
\hline $\mathrm{EMB} \mathrm{G}_{1}$ & + & Cocci & - & - & - & + & + & + & $\mathrm{S}$ & $\mathrm{S}$ & Ruminococcus albus \\
\hline $\mathrm{EMB} \mathrm{G}_{2}{ }^{\mathrm{a}}$ & + & Rods & + & + & + & + & + & + & $\mathrm{S}$ & $\mathrm{S}$ & Lactobacillus ruminus \\
\hline $\mathrm{EMB} \mathrm{G}_{2}{ }^{\mathrm{b}}$ & - & Rods & - & - & - & + & + & + & $\mathrm{R}$ & $\mathrm{S}$ & Bacteroides succinogenes \\
\hline $\mathrm{EMB} \mathrm{G}_{4}{ }^{\mathrm{a}}$ & + & Cocci & - & - & - & + & + & + & $\mathrm{S}$ & $\mathrm{S}$ & Ruminococcus albus \\
\hline $\mathrm{EMB} \mathrm{G}_{4}{ }^{\mathrm{b}}$ & + & Rods & + & + & + & + & + & + & $\mathrm{S}$ & S & Lactobacillus ruminus \\
\hline $\mathrm{EMB} \mathrm{G}_{7}$ & - & Rods & - & - & - & + & + & + & $\mathrm{R}$ & $\mathrm{S}$ & Bacteroides succinogenes \\
\hline
\end{tabular}






Table 4 Morphological and biochemical test of the rumen fungal isolates

\begin{tabular}{|c|c|c|c|c|c|c|c|c|c|c|c|c|c|}
\hline \multirow{3}{*}{$\begin{array}{c}\text { Isolate } \\
\text { code No. }\end{array}$} & \multicolumn{6}{|c|}{ Morphological examination } & \multicolumn{6}{|c|}{ Biochemical Test } & \multirow{3}{*}{$\begin{array}{c}\text { Identification } \\
\text { Suspected } \\
\text { microorganism }\end{array}$} \\
\hline & \multicolumn{6}{|c|}{ Structure } & \multicolumn{6}{|c|}{ Starch fermentation } & \\
\hline & Col & Cell & Myc & Rhi & Rep & Spo & Pec & Malt & Glu & Gal & Lac & Hcell & \\
\hline $\mathrm{PDA} \mathrm{C}_{1}^{\mathrm{a}}$ & ND & Poly & ND & ND & ND & ND & + & + & + & - & + & + & Orpinomyces joyonii \\
\hline $\mathrm{PDA} \mathrm{C}_{1}^{\mathrm{b}}$ & ND & Poly & ND & ND & ND & ND & + & + & + & - & + & + & O. joyonii \\
\hline $\mathrm{PDA} \mathrm{C}_{3}$ & ND & Mono & ND & ND & ND & ND & - & + & + & - & + & + & Neocallimastix frontalis \\
\hline $\mathrm{PDA} \mathrm{C}_{4}$ & ND & Mono & ND & ND & ND & ND & - & - & + & - & - & - & Caecomyces communis \\
\hline $\mathrm{PDA} \mathrm{C}_{5}{ }^{\mathrm{a}}$ & ND & ND & ND & ND & Bud & ND & + & + & + & + & + & + & Saccharomyces cerevisiae \\
\hline $\mathrm{PDA} \mathrm{C}_{5}{ }^{\mathrm{b}}$ & ND & ND & ND & ND & Bud & ND & + & + & + & + & + & + & S. cerevisiae \\
\hline $\mathrm{PDA} \mathrm{C}_{6}$ & ND & Mono & ND & ND & ND & ND & - & + & + & - & + & + & N. frontalis \\
\hline $\mathrm{PDACC}_{7}^{\mathrm{a}}$ & ND & Mono & ND & ND & ND & ND & - & + & + & - & + & + & N. frontalis \\
\hline $\mathrm{PDAC} \mathrm{C}_{7}^{\mathrm{b}}$ & White/brown/yellow & CAM & Asep & Abs & Нyp & Bran & ND & ND & ND & ND & ND & ND & Mucor spp \\
\hline $\mathrm{PDA} \mathrm{C}_{7}^{\mathrm{c}}$ & White/brown/yellow & CAM & Asep & Abs & Hyp & Bran & ND & ND & ND & ND & ND & ND & Mucor spp \\
\hline $\mathrm{PDA} \mathrm{C}_{7}^{\mathrm{d}}$ & White/gray & DCAM & Asp & Pre & Hyp & Unbra & ND & ND & ND & ND & ND & ND & Rhizopus spp \\
\hline $\mathrm{PDAC}_{8}$ & ND & Poly & ND & ND & ND & ND & + & + & + & - & + & + & O. joyonii \\
\hline $\mathrm{PDAC}_{9}$ & ND & Mono & ND & ND & ND & ND & - & + & + & - & + & + & $N$. frontalis \\
\hline $\mathrm{PDA} \mathrm{C}_{10}$ & ND & Poly & ND & ND & ND & ND & + & + & + & - & + & + & O. joyonii \\
\hline $\mathrm{PDA} \mathrm{G}_{1}$ & ND & Mono & ND & ND & ND & ND & - & - & + & - & - & - & C. communis \\
\hline $\mathrm{PDA} \mathrm{G}_{2}$ & ND & Mono & ND & ND & ND & ND & - & + & + & - & + & + & N. frontalis \\
\hline $\mathrm{PDA} \mathrm{G}_{3}$ & ND & Mono & ND & ND & ND & ND & - & - & + & - & - & - & C. communis \\
\hline $\mathrm{PDA} \mathrm{C}_{4}$ & ND & Mono & ND & ND & ND & ND & - & + & + & - & + & + & N. frontalis \\
\hline $\mathrm{PDA} \mathrm{C}_{6}{ }^{\mathrm{a}}$ & ND & Poly & ND & ND & ND & ND & + & + & + & - & + & + & O. joyonii \\
\hline $\mathrm{PDA} \mathrm{C}_{6}^{\mathrm{b}}$ & White/brown/yellow & CAM & Asep & Abs & Hyp & Bran & ND & ND & ND & ND & ND & ND & Mucor spp \\
\hline $\mathrm{PDAC} \mathrm{C}_{7}^{\mathrm{a}}$ & ND & Poly & ND & ND & ND & ND & + & + & + & - & + & + & O. joyonii \\
\hline $\mathrm{PDA} \mathrm{C}_{7}^{\mathrm{b}}$ & White/brown /yellow & CAM & Asep & Abs & Hyp & Bran & ND & ND & ND & ND & ND & ND & Mucor spp \\
\hline $\mathrm{PDA} \mathrm{G}_{7}^{\mathrm{c}}$ & White/gray & DCAM & Asep & Pre & Hyp & Unbra & ND & ND & ND & ND & ND & ND & Rhizopus spp \\
\hline $\mathrm{PDA} \mathrm{G}_{8}$ & ND & ND & ND & ND & Bud & ND & + & + & + & + & + & + & S. cerevisiae \\
\hline $\mathrm{PDA} \mathrm{G}_{9}$ & ND & ND & ND & ND & Bud & ND & + & + & + & + & + & + & S. cerevisiae \\
\hline PDA $G_{10}{ }^{a}$ & ND & Mono & ND & ND & ND & ND & - & + & + & - & + & + & N. frontalis \\
\hline PDA $G_{10}{ }^{b}$ & White/gray & DCAM & Asep & Pre & Hyp & Unbra & ND & ND & ND & $\mathrm{ND}$ & $\mathrm{ND}$ & ND & Rhizopus spp \\
\hline
\end{tabular}

$N D=$ Not determined; $C o l=$ Colour; $M y c=$ Mycelium; Rhi $=$ Rhizoid $; C_{1}-C_{10}=$ Isolates from cattle rumen liquor; $-=$ Negative response; $G_{1}-G_{10}=$ Isolates from goats rumen liquor $+=$ Positive response $;$ Rep $=$ Reproductive stage $;$ PDA = Potato Dextrose Agar $;$ Spo $=$ Sporangiophore $;$ Pec $=$ Pectin $;$ Malt $=$ Maltose $;$ Glu $=$ Glucose $;$ Gal = Galactose $;$ Lac = Lactose; Hcell = Hemicellulose; Poly = Polycentric; Mono = Monocentric; Hyp = Hyphae; Abs = Absent $;$ Pre = Present; Asp = Aseptate; Unbra = Unbranched; Bran = Branched CAM = Cottony aerial mycelium; DCAM = Dense cottony aerial mycelium.

The minimum inhibition concentration of $S$. mombin foliage extract on the rumen microorganisms is expressed in Table 5. All the treatments were observed to absolutely inhibited (2mm MIC) Butyrivibrio fibrisolvens, Ruminococcus flavefaciens, Bacteroides ruminicola, Streptococcus bovis and Lactobacillus ruminus and mildly inhibited (1.60 - 1.62mm MIC) Bacteroides succinogenes. Air-dried and sun-dried samples were also observed to absolutely inhibited ( $2 \mathrm{~mm}$ MIC) Selenomonas ruminantium and mildly inhibited $(1.51-1.52 \mathrm{~mm} \mathrm{MIC})$ Ruminococcus albus. Similarly, sun-dried and fresh samples absolutely inhibited (2mm MIC) Caecomyces communis, Saccharomyces cerevisiae and Neocallimastix frontalis but Orpinomyces joyonii was mildly inhibited $(0.31$ $1.31 \mathrm{~mm}$ MIC). On the other hand, it was discovered that Mucor and Rhizopus species were absolutely insusceptible $(0.0 \mathrm{~mm}$ MIC) to all the treatments.

It was shown that all the rumen microorganisms were susceptible to the processed S. mombin foliage pure extract except, Mucor and Rhizopus species that were absolutely not inhibited, indicating that dry processing technique may not improve rumen microbial degradation and subsequent nutrient utilization of feedstuff resource by the host as reported by some scientists (Olomu, 2011; Hoskin et al., 1997; Makkar and Becker (1996). The observed toxic potential of $S$. Mombin foliage to rumen microorganisms, agreed with the reports in extracts of Vernonia amygdalina, Chamaecytisus palmensis, Sesbania sesban, Acacia angustissima and Leucaena leucocephala that affected the growth of pure culture of Cellulolytic bacteria (Osuji et al., 1995). However, it contradicted the report of Makkar and Becker (1996) in Moringa oleifera leave extract where uninhibited microbial growth was recorded.

The cause of high degree susceptibility observed in the present study is somewhat not clear because the antinutrients concentrations in browse plants reported by several scientists to be a possible cause of rumen microbial toxicity vis-à-vis host ruminant were tremendously reduced by the feedstuff processing techniques evaluated in the present study. Meanwhile, it could be due to the growth media used, number of punched-well, foliage extract concentration and probably due to the medium of extraction. The absolute insusceptibility of the mould species could simply be due to their characteristics mode of growth.
Table 5 Physiological response of rumen microorganisms to ethanolic extract of S. mombin foliage

\begin{tabular}{lcccc} 
Rumen & \multicolumn{3}{c}{ Minimum inhibition concentration (mm) } \\
\cline { 2 - 5 } microorganisms & Fresh & Air-dried & Sun-dried & SEM \\
S. ruminantium & & & & \\
R. albus & $1.04^{\mathrm{a}}$ & $2.00^{\mathrm{b}}$ & $2.00^{\mathrm{b}}$ & 0.35 \\
B. fibrisolvens & $2.00^{\mathrm{b}}$ & $1.51^{\mathrm{a}}$ & $1.51^{\mathrm{a}}$ & 0.16 \\
R. flavefaciens & 2.00 & 2.00 & 2.00 & 0.003 \\
B. ruminicola & 2.00 & 2.00 & 2.00 & 0.003 \\
B. succinogenes & 2.00 & 2.00 & 2.00 & 0.003 \\
S. bovis & 1.61 & 1.62 & 1.60 & 0.006 \\
L. ruminus & 2.00 & 2.00 & 2.00 & 0.003 \\
& 2.00 & 2.00 & 2.00 & 0.003
\end{tabular}

\section{Fungi}

\begin{tabular}{lcccc} 
Fungi & & & \\
O. joyonii & $1.31^{\mathrm{b}}$ & $0.31^{\mathrm{a}}$ & $1.03^{\mathrm{b}}$ & 0.29 \\
N. frontalis & $2.00^{\mathrm{b}}$ & $1.51^{\mathrm{a}}$ & $1.52^{\mathrm{a}}$ & 0.16 \\
C. communis & $1.31^{\mathrm{a}}$ & $1.30^{\mathrm{a}}$ & $2.00^{\mathrm{b}}$ & 0.24 \\
S. cerevisiae & $1.51^{\mathrm{b}}$ & $1.01^{\mathrm{a}}$ & $2.00^{\mathrm{c}}$ & 0.29 \\
Mucor species & 0.0 & 0.0 & 0.0 & 0.03 \\
Rhizopus species & 0.0 & 0.0 & 0.0 & 0.003 \\
\hline
\end{tabular}

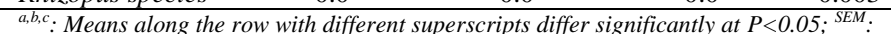
Standard error of means.

The approach used in this study where pure culture rumen microorganisms were exposed to feedstuff sample in vitro could be a novel and better technique of feed quality evaluation. Besides, it may be more economical compared to the digestion technique, nylon bags technique, gas production technique and cell-free fungal cellulose technique described by other scientists. This is because the outcome from the mixed rumen microbial culture as adopted in other techniques does not actually reflect which microorganism is actively involved in the fermentation and degradation processes in the feedstuffs as shown in Sullivan and Martin (1999). More so, the experimental outcome takes lesser time cannulation is not required and above all, many feed resources can be assessed at the same time. Although in vitro results may not conform to in vivo trial, the present study is targeted at encapsulating myriads of known rumen 
microorganisms that would be made available in commercial quantity for feed resource quality rapid test anywhere in the world.

\section{CONCLUSIONS}

The results revealed that drying technique significantly improved the proximate fibre and mineral compositions of $S$. mombin foliage. In contrast, all the vitamins determined were considerably reduced by drying. Similarly, the concentrations of all the antinutrients were significantly lowered by drying. As a result, drying of feed resources may be necessary prior to utilization in ruminant feeding. On the other hand, all the rumen microorganisms exposed to the $S$. mombin foliage extract were susceptible except the mould species. This apparently indicated that drying may not be proficient in reducing the toxic potential of $S$. mombin foliage However, the observed nutritional quality potentials suggested that $S$. mombin foliage may be efficiently utilized by ruminants for optimal performance Although, it has been established that rumen fermentation is the net result of different microorganisms interactions in the rumen ecosystem, the present findings may not conform to in vivo feedstuff trial. Thus, ruminant feeding tria to elucidate $S$. mombin foliage suitability for prompt adoption and utilization or otherwise is required.

\section{REFERENCES}

ADERINBOYE, R.Y., ONWUKA, C.F.I. 2010. Regulatory effect of monesin of feed intake and weight gain in WAD sheep fed high forage diet. (Proc. $35^{\text {th }}$ Conf.), NSAP, UI, Nigeria, 524-526.

AHN, J.H., ROBERTSON. B.M., ELLIOT, R,, GUTERIDGE, R.C., FORD C.W. 1989. Quality assessment of tropical browse legumes: Tannin content and protein degradation. Anim. Feed Sci. Technol., 27, 147 - 156. Acessed in: http://dx.doi.org/10.1016/0377-8401(89)90139-9.

AOAC. 2000. Official methods of analysis, Association of Official Analytical Chemists $\left(17^{\text {th }}\right.$ edn.), Washington D.C.

BARRY, T.N., McNABB, W.C. 1999. The implication of condensed, tannins on the nutritive value of temperate forages fed to ruminants. Brit. J. Nutr., 81, 263 272. Acessed in: http://dx.doi.org/10.1017/S0007114599000501

BATEMAN, D.F., BEER, S.V. 1965. Simultaneous production and synergistic action of oxalic acid and polygalacturonase during pathogenesis by Sclerotium rolfsii. J. Photopathol., 55, 204-211. Acessed in: [PubMed]

BLACK, J.G. 1986. Microbiology. Principles and application ( $2^{\text {nd }}$ edn.) WCB/McGraw-Hill, 775 p.

BRADBURY, M.G., EGAN, S.V., BRADBURY, J.H. 1999. Determination of all forms of cyanogens in cassava roots and cassava products using picrate paper kits. J. Sci. Food Agric., 79: 593-601. Acessed in: Volume 79, Issue 4,

CHURCH, D.C. 1993. The Ruminant Animal Digestive physiology and Nutrition. Wakeland Press Inc: Illinois, 564 p.

COELHO, M. 1999. Vitamin Stability in Premixes and Feeds A Practical Approach in Ruminant Diets (Proceedings $13^{\text {th }}$ Annual Florida Ruminant Nutrition Symposium), Florida USA, 127-145.

D'MELLO, J.P.F., FRASER KW 1981. The composition of leaf meal from Leucaena leucocephala. J. Trop. Sci., 23, 75-78. Acessed in: http://www.pjbs.org/ijps/fin1772.pdf Full Text .DOI: 10.1007/978-94-011-40188 825.

De-BOEVER, J.L., COTTON, B.G., BUYSSE, F.X., WAINMAN, F.W., VAMACKER, J.M. 1986. The use of an enzymatic technique to predict digestibility, metabolizable and energy of compound feedstuffs for ruminants Anim. Feed Sci. Technol., 14, 203-214. DOI: 10.1016/0377-8401(86)90093-3. Acessed in: Direct Link.

ESGPIP. 2008. Formulation of rations for sheep and goats. Ethiopia sheep and Goat Productivity improvement program. Techn. Bull. No.16.

GADIENT, M. 1986. Effect of pelleting on nutritional quality of feed. In :Proceeding of Maryland Nutritional Conference, College Park, MD. University of Maryland, College Park, 73-79.

GIVENS, D.I., OWEN, E., AXFORD, R.F.E., OHMED, H.M. 2000. Forage evaluation in ruminant nutrition. CABI Publication Wallingford, U.K

HENRY, T.A. 1973. The plant Alkaloids. In: Butter, G.W. and Bailey, R.W. (eds.). Chemistry and Biochemistry of Herbage. Academic Press: N.Y., 466 p. HOSKIN, S.O., BARRY, T.N., WILSON, P.R., CHARLESTON, W.A.G., WAGHORM, G.C. 1997. Development of a model to study internal parasites in red deer and effects of forages containing condensed tannins upon their establishment. New Zealand J. Zool. 26, 75. Acessed in: www.sciencedirect.com/science/article/pii/S0304401702000146. 24/04/2004 IDAHOR, K.O., USMAN, A. AND RAJI, A.O. 2012. Comparison of the fibre fractions, vitamins and minerals contents of cowpea and sorghum husk proposed for ruminant nutrition. (Proc. $37^{\text {th }}$ Ann. Conf.) NSAP, UAM, 535-537.

IDU, M., ATAMAN, J.E., AKHIGBE, A.O., UCHO, O.G., AKINBO, S.F., IDU, F.K. 2002. Studies on the nutritional value and antitumour property of the bark of S. mombin L. J. Med. Biomed Res., 1(2), 61. Acessed in: http://www.ijpbs.net/vol-3/issue-4/Bio/1. 12/12/2003.
IKHIMIOYA, I., ORIAKHI, A.I. 2004. Proximate composition of fresh and dry leaves of some shrubs and trees eaten by small ruminants in the derived savannah of Edo State, Nigeria. (Proc. 29 ${ }^{\text {th }}$ Ann. Conf., NSAP), UDU, Sokoto, 139-141. KUDO, H., JACOBER, K.D., PHILLIPE, R.C., CHENG, K.J., BAR, D.J.S., COSTERTON, J.W. 1990. Isolation and characterization of cellulolytic anaerobic fungi and associated mycoplasms from the rumen of steer fed a roughage diet. Canad. J. Microbiol., 36, 513-517. Acessed in: Medline Google Scholar

LEVETT, P.N. 1990. Anaerobic Bacteria. A Functional Biology. Open University Press: Philadelphia, 122 p.

LIENER, I.E. 1955. The photometric determination of haemaglutinin activity of soyin and soyabean extracts. Arch. Biochem. Biophys., 5, 223-231. Acessed in Arch Biochem Biophys. [PubMed].

MAKKAR, H.P.S., BECKER, K. 1996. Nutritional value and antinutritional components of whole and ethanol extracted Moringa oleifera leaves. Anim. Feed Sci. Technol., 63, 211-228. Acessed in: http://dx.doi.org/10.1016/S03778401(96)01023-1

MAKKAR, H.P.S. 2004. Recent advances in in vitro gas method for evaluation of nutritional quality of feed resources. Assessing quality and safety of animal feeds. Food and Agricultural Organisation, Rome. Acessed in http://www.fao.org/documents Agriculture and Consumer Protection PDF version ZIP version

MAKKAR, H.P.S., BLUMMEL, M., BOROWY, N.K., BECKER, K. 1993. Gravimetric determination of tannins and their correlations with chemical and protein precipitation methods. J. Sci Food Agric., 61, 161-165. Acessed in www.fao.org/docrep/ARTICLE/AGRIPPA/570_EN-04.htm.

MECHA, I., ADEGBOLA, T.A. 2004. Chemical composition of some southern Nigerian forage eaten by goats. Accessed in http://www.ilri.cgiar.org/Infosev/Webpub/Fulldocs/Browse-in-

Africa/Chapter30.htm.,22/02/2006.

MEGARRITY, R.G. 1978. An automated colorimetric method for mimosine in Leucaena leaves. J. Sci. Food Agric. 29:182-186. Acessed in: CrossRef PubMed Doi: 10.1002/jsfa.2740290216 MEHREZ, A.Z., ORSKOV, E.R. 1977. A study of artificial fibre bag technique for determining the digestibility of feeds in the rumen. J. Agric. Sci., 88, 645-650 Acessed in: www.fao.org/docrep/006/AD236E/ad236e13.htm. 16/08/2006 MENKE, K.H., RAAB, L., SALEWSKI, A., STEINGASS, H., FRITZ, D., SCHNEIDER, W. 1979. The estimation of the digestibility and metabolisable energy content of ruminant feedstuffs from the gas production when they are incubated with rumen liquor in vitro. J. Agric. Sci., 92, 217-222.Acessed in www.fao.org/docrep/ARTICLE/AGRIPPA/570_EN-04.htm. 27/01/2006 MIDKIFF, V. 1984. A century of analytical excellence. The history of feed analysis as chronicled in the development of AOAC Official Methods (1884 1984). J. Assoc. Offic. Anal. Chem., 67, 851-860. Acessed in: http://www.fao.org/docrep/007/y5159e/y5159e03.htm. 29/08/2009.

NRC. 1981. Nutrient requirements of goats: Angora, dairy and meat goats in temperate and tropical countries. National Research Council, National Academy of Science: Washington DC, USA.

OLOMU, J.M. 2011. Monogastric Animal Nutrition. Principles and Practice $\left(2^{\text {nd }}\right.$ edn). St. Jackson Publication: Benin City, Nigeria, 478 p.

OSUJI, P.O., FERNANDEZ-RIVERA, S., ODENYO, A. 1995. Improving fibre utilization and protein supply in animals fed poor quality roughages. (Proceedings and Workshop), ILRI: Nairobi, 1-22.

REED, J.D. 1986. Relationship among soluble phenolics, insoluble proanthocyanidins and fibre in East African browse species. J. Range Manag., 39, 5. Acessed in: www.fao.org/wairdocs/ilri/x5536e/x5536e18.htm. 17/10/2010. ROSIJI, O.G., IPOSU, S.O. 2002. Potentials of oil palm leaves as a ruminant feed resources: Proximate composition. (Proc. $27^{\text {th }}$ Ann. Conf.,) NSAP, FUTA, 185-187.

SAS. 1999. Statistical Analysis Software (SAS/STAT) users guide. Version 8 for Windows SAS Institute Inc: Campus Drive, carry: North Carolina, USA. SCHNEIDER, J. 1986. Synthesis; formulation and stability of vitamins. Proceedings of the Twenty-second Annual Nutrition Conference for Feed Manufacturers, 18.

SMITH, C., VAN MEGAN, W., TWAALCHOVEN, L., HITCHCOCK, C. 1980 The determination of trypsin inhibitor levels in foodstuffs. J. Sci,. Food Agric., 31 , 341-350. Acessed in www.medwelljournals.com/ref.php?doi=javaa.2011.214.220. 11/1/2011.

SULLIVAN, H.M., MARTIN, S.A. 1999. Effects of a Saccharomyces cerevisiae culture on in vitro mixed ruminal microorganisms fermentation J. Dairy Sci., 82 (9), 2011-2016. Acessed in: www.journalofdairyscience.org/article/S00220302(99)75438. 25/03/2006

TANGENDJAJA, B., REHARDJO, Y.C., LOWRY, J.B. 1990. Leucaena leaf meal in the diet of growing rabbits. Evaluation and effect of a low-mimosine treatment. Anim. Feed Sci. Technol., 29, 63-72. Acessed in www.pjbs.org/ijps/fin1772. 18/09/2004.

TILLEY, J.M., TERRY, R.A. 1963. A two stage technique for in vitro digestion of forage crops. J. Brit. Grassl Soc., 18, 104-111. Acessed in www.fao.org/ag/aga/agap/frg/tap64/64_287.08/08/2006. 
VAINTRAUB, I.A., LAPTEVA, N.A. 1988. Colorimetric determination of phytate in unpurified extracts of seeds and the products of their processing. $J$. Anal. Biochem., 175, 227-230. (PMID:3245569) Acessed in: Vaintraub IA, Lapteva NA

van SOEST, P.J., ROBERTSON, J.B., LEWIS, B.A. 1991. Methods for dietary fibre, neutral detergent fibre and non starch polysaccharides in relation to animal nutrition. J. Dairy Sci. 74, 3583-3593. Acessed in www.scielo.org.ve/scielo.php?pid=S0798-22592006000100010...sci. 22/06/2005 WIERSEMA, J.H., LEON, B. 1999. World Economic Plants. A Standard Reference. CRC Press, Washington D.C., 749 p.

WISEMAN, J., COLE, D.J.A. 1990. Feedstuff Evaluation. Butterwort: London, $780 \mathrm{p}$.

WITT, N. 1987. Determination of energy in grass and silage by calorimetry. Proc. $8^{\text {th }}$ Silage Conf., Hurley, UK, p. 147.

YOKOYAMA, M.T., JOHNSON, K.A. 1993. Microbiology of the rumen and intestine. In: Church, D.C. (ed.). The Ruminant Animal Digestive Physiology and Nutrition. Waveland Press Inc: Illinois, 269-297. 